\title{
PERAN GURU DALAM MEMOTIVASI BELAJAR SISWA KELAS V SDN O04 SEI BEBERAS HILIR KECAMATAN LUBUK BATU JAYA KABUPATEN INDRAGIRI HULU
}

\author{
Tri Widyastuti ${ }^{1}$, Elpri Darta Putra ${ }^{1}$ \\ ${ }^{1}$ Universitas Islam Riau, Indonesia \\ *Corresponding email: triwidyastuti777@gmail.com
}

Naskah diterima: 10 Juli 2021| Disetujui: 7 Agustus2021 | Diterbitkan: 20 Agustus 2021

\begin{abstract}
This study aims to find out how the teacher's role in motivating student learning besides the purpose of this study is to find out what obstacles are experienced by teachers in motivating student learning. This research uses a qualitative approach which is a case study. The data sources for this research are 1 class $V$ teacher, 1 class $I V$ teacher, and 2 students. There are four results obtained, the first is the teacher as a demonstrator, namely mastery of learning material by motivating student learning, the second is the teacher as a class manager, namely creating a learning climate in learning by motivating student learning, the third is the teacher as a mediator and facilitator, namely preparing the syllabus, lesson plans, and learning media, instill a spirit of student learning, and provide motivation in learning, and the fourth teacher as an evaluator is the evaluation results. Barriers experienced by teachers in motivating student learning include the teacher's lack of motivation or encouragement in learning due to the impact of covid-19, the role of the teacher becomes a much needed role in learning in motivating student learning so that students are more diligent and not lazy in learning.
\end{abstract}

Keywords: teacher's role, student's learning motivation.

Abstrak: Penelitian ini bertujuan untuk mengetahui bagaimana peran guru dalam memotivasi belajar siswa dan mengetahui apa saja hambatan yang dialami oleh guru dalam memotivasi belajar siswa. Penelitian ini menggunakan pendekatan kualitatif bersifat studi kasus. Sumber data penelitian ini adalah seorang orang guru kelas $\mathrm{V}$, seorang guru kelas IV, dan dua orang siswa. Teknik pengumpulan data menggunakan metode wawancara dan observasi, sedangkan analisis data penelitian menggunakan model Miles \& Huberman yang meliputi reduksi data, penyajian, dan penarikan kesimpulan. Hasil penelitian menunjuukan bahwa guru sebagai demonstrator, yaitu penguasaan materi pembelajaran dengan memotivasi belajar siswa. Guru sebagai pengelola kelas, yaitu menciptakan iklim belajar di dalam pembelajaran dengan memotivasi belajar siswa. Guru sebagai mediator dan fasilitator, yaitu penyiapan silabus, RPP, dan media pembelajaran, menanamkan semangat belajar siswa, dan memberikan motivasi dalam pembelajaran. Guru sebagai evaluator, yaitu hasil evaluasi. Hambatan yang dialami oleh guru dalam memotivasi belajar siswa di antaranya guru kurang menerapkan motivasi atau dorongan dalam pembelajaran, akibat dampak covid-19 peran guru menjadi peran yang sangat dibutuhkan dalam pembelajaran untuk memotivasi siswa agar lebih rajin dan tidak malas dalam belajar.

Kata kunci: peran guru, motivasi belajar siswa. 


\section{PENDAHULUAN}

Pendidikan merupakan proses untuk mendidik serta menuntut siswa untuk mencapai tujuan tertentu dalam bentuk perubahan ke arah yang positif dalam diri siswa. Perubahan yang diinginkan merupakan bagian dari sebuah proses menuju kedewasaan yang berlangsung terus menerus dalam kehidupan siswa. Keberhasilan pendidikan di sekolah tergantung pada kualitas guru, dengan kata lain guru harus profesional dalam mendidik. Pendidikan di sekolah merupakan kegiatan proses pembelajaran dengan adanya guru dan siswa melalui proses pengajaran dan pelatihan yang diberikan oleh guru untuk anak didiknya.

Guru merupakan sosok arsitektur yang dapat membentuk jiwa dan watak siswa, serta membangun kepribadian menjadi seseorang yang berguna bagi agama, nusa, dan bangsa. Guru bertugas mempersiapkan manusia susila diharapkan membangun dirinya, membangun bangsa dan negara. Dengan demikian guru memberikan ilmu dan membangun kepribadian siswa untuk mencapai tujuannya (Supardi, 2013).

Selaku pendidik, guru wajib memahami ilmu pengetahuan yang luas, memahami bahan pelajaran dan ilmu-ilmu yang bertalian dengan mata pelajaran ataupun bidang riset yang diajarkan, memahami teori serta praktek mendidik, teori kurikulum tata cara pengajaran, teknologi pembelajaran, teori penilaian psikologi belajar, dan lain sebagainya. Motivasi yang dapat diberikan kepada siswa dalam hal ini adalah memberi angka. Angka dalam hal ini merupakan simbol dari nilai aktivitas belajar siswa. Banyak siswa belajar hanya untuk menggapai angka atau nilai yang baik. Sehingga dapat dikatakan bahwa guru mempunyai peranan besar dalam proses pembelajaran siswa.

Motivasi belajar merupakan keseluruhan daya penggerak dalam diri siswa yang sanggup menimbulkan kegiatan belajar yang menjamin kelangsungan dari kegiatan belajar, serta memberikan arahan pada kegiatan belajar. Sehingga tujuan yang dikehendaki oleh subjek belajar dapat tercapai (Hero \& Sni, 2018). Motivasi belajar yang dimaksud sebagai daya penggerak dalam diri siswa sehingga menimbulkan keinginan untuk ingin belajar. Keberhasilan belajar seorang anak dapat dilihat dari motivasi belajar yang dimiliki anak. Siswa yang memiliki motivasi rendah maka prestasi belajarnya akan renda pula. Sebab motivasi berasal dari dalam diri yang menjadi pendorong dan penggerak untuk melakukan suatu tindakan tertentu. Tinggi dan rendahnya motivasi seseorang dapat dilihat dari semangat seseorang untuk melakukan suatu aktivitas, sehingga tinggi rendahnya suatu semangat akan menunjukkan hasil yang diperoleh seseorang.

Peran guru dan orang tua sangat berpengaruh dalam menentukan keberhasilan anak terutama dalam hal meningkatkan motivasi belajar peserta didik. Guru dan orang tua juga berperan dalam meningkatkan potensi anak, seperti potensi efektif, potensi kognitif, dan potensi psikomotorik. Ada 
beberapa peran guru untuk meningkatkan motivasi dan semangat anak dalam belajar, seperti guru menggunakan media, metode, dan model pembelajaran yang tepat pada saat mengajar. Guru juga harus memahami serta mengatasi kesulitan belajar anak atau siswa.

Berdasarkan wawancara yang dilakukan dengan guru kelas V SDN 004 Sei Beberas Hilir, pada tanggal 5 Januari 2021 selaku pendidikan yang bertanggung jawab penuh menyatakan terkendala oleh beberapa permasalahan mengenai siswa dalam terjadinya proses belajar mengajar. Salah satu penyebabnya adalah perbedaan karakter pada setiap siswa yang dihadapi oleh guru terutama dalam hal memotivasi siswa dalam menanggapi pembelajaran di sekolah. Wawancara dengan salah satu guru kelas V SDN 004 Sei Beberas Hilir memperoleh hasil bahwa siswa tidak fokus dalam pembelajaran, siswa lebih sering bermain dengan teman-teman, sebagian siswa tidak semangat dalam pembelajaran, dan siswa lamban dalam belajar.

Hal di atas jika perhatian guru dalam memotivasi siswa terkesan rendah dapat mempengaruhi hasil belajar, banyak hal yang dapat dilihat dari perilaku dan tingkah laku anak, antara lain sikap anak yang kurang dalam memperhatikan guru, anak yang suka mengganggu teman sekelasnya pada saat proses pembelajaran berlangsung, suka menyontek hasil pekerjaan temannya, tidak mengerjakan tugas yang diberikan oleh guru, dan nilai tugas maupun ulangan siswa yang rendah.

\section{METODE}

Metode yang digunakan dalam penelitian ini adalah deskriptif dengan pendekatan kualitatif. Penelitian kualitatif merupakan metode penelitian yang berlandaskan pada filsafat postpositivisme, digunakan untuk meneliti pada kondisi obyek yang alamiah (Sugiyono, 2015). Penelitian ini mendeskripsikan peran guru dalam memotivasi belajar siswa kelas V SDN 004 Sei Beberas Hilir Kecamatan Lubuk Batu Jaya Kabupaten Indragiri Hulu.

Penelitian dilaksanakan secara bertahap, peneliti merencanakan penelitian pada bulan Febuari 2021 sampai dengan juli 2021. Teknik pengumpulan data dalam penelitian ini adalah wawancara, observasi, dan dokumentasi. Instrumen dalam penelitian adalah penelitian itu sendiri (Sugiyono, 2014). Analisis data menggunakan model Miles dan Huberman yang berlangsung secara terus menerus dengan tahap reduksi data (data reduction), penyajian data (data display), penarikan kesimpulan (conclusion drawing) (Gunawan, 2013). 


\section{HASIL DAN PEMBAHASAN}

Peran guru dalam memotivasi ekstrinsik siswa kelas V SDN 004 Sei Beberas Hilir. dapat diklasifikasikan sebagai berikut.

1. Guru selaku demonstrator. Melalui perannya guru sebaiknya memahami bahan ataupun modul belajaran yang hendak diajarkan serta mengembangkannya, sebab perihal ini bakal menentukan hasil belajar yang dicapai oleh siswa.

2. Guru selaku pengelola kelas (learning managers). Guru sebaiknya sanggup melaksanakan penindakan pada kelas, sebab kelas ialah lingkungan yang butuh diorganisasi.

3. Guru selaku mediator dan fasilitator. Selaku mediator guru sebaiknya mempunyai pengetahuan serta uraian yang cukup untuk media pembelajaran, sebab media pembelajaran ialah perlengkapan komunikasi guna lebih mengefektifkan proses belajar mengajar. Begitu pula guru selaku fasilitator, guru sebaiknya sanggup mengusahakan sumber belajar yang rasanya bermanfaat dan bisa mendukung pencapaian tujuan serta proses belajar mengajar, baik yang berbentuk narasumber, novel bacaan, majalah, maupun pesan berita.

4. Guru selaku evaluator yang baik, guru sebaiknya melaksanakan evaluasi untuk mengenali apakah tujuan yang sudah diformulasikan itu tercapai apa tidak, apakah modul yang diajarkan sudah dipahami atau belum oleh siswa, serta apakah tata cara yang digunakan sudah tepat.

5. Berdasarkan hasil wawancara dan hasil observasi yang telah dilakukan oleh penulis maka dapat disimpulkan bahwa pembelajaran yang ada di SDN 004 Sei Beberas Hilir, guru sudah melaksanakan pembelajaran sesuai dengan dinas pendidikan yaitu pembelajaran di buat melalui RPP, silabus, dan menggunkan media. Selain itu guru sudah menguasai materi pembelajaran tetapi guru belum menerapkan motivasi belajar dengan karakter siswa yang berbeda-beda. Hasil wawancara menunjukkan bahwa siswa lebih suka suasana pembelajaran bermain sambil belajar dan siswa lebih semangat belajar jika pembelajaran dilakukan dengan soal-soal yang menantang dan diberi reward.

Hambatan yang dialami guru dalam memotivasi belajar siswa kelas V Di SDN 004 Sei Beberas Hilir, yaitu guru sebagai demonstrator. Berdasarkan hasil wawancara yang telah dilakukan dengan guru kelas V dan guru kelas IV, hambatan dalam penguasaan materi belajar yaitu ketika pembelajaran daring dilakukan guru kelas V Ibu Jiyem. Beliau menyatakan bahwa ia kurang menguasai dalam menjalankan motivasi belajar untuk siswa, sedangkan menurut guru kelas IV Ibu Sumarni bahwa guru harus lebih kreatif untuk membangkitkan motivasi belajar siswa.

Berdasarkan hasil observasi yang telah dilakukan penulis, hambatan guru kelas V dalam menciptakan iklim belajar yaitu motivasi siswa dalam pembelajaran belum dikuasai oleh guru, 
sedangkan dari guru kelas IV motivasi belajar sudah dilaksanakan, tetapi guru masih harus belajar bagaimana membangkitkan motivasi siswa. Berdasarkan dari hasil wawancara dan observasi yang telah dilakukan, dapat diartikan bahwa hambatan guru kelas V dan guru kelas IV adalah kurangnya motivasi belajar dengan karakter siswa yang berbeda-beda dalam keadaan belajar offline maupun daring.

Berdasarkan hasil wawancara dan observasi guru kelas $\mathrm{V}$ dan guru kelas IV menunjukkan bahwa keduanya sama-sama tidak memiliki hambatan dalam pekerjaan hasil evaluasi karena dalam daftar nilai mereka sama-sama memiliki nilai-nilai motivasi belajar yang baik terhadap siswa, contohnya nilai tambahan tingkah laku dan nilai keaktifan siswa yang di buat dalam 1 laporan, biasanya disebut daftar nilai. Berdasarkan hasil wawancara dan observasi yang telah dilakukan oleh penulis, dapat disimpulkan bahwa hambatan yang dialami oleh guru dalam memotivasi belajar siswa kelas V yaitu kurangnya pemahaman dalam melaksanakan motivasi belajar kepada siswa dalam pembelajaran, dengan keadaan pembelajaran yang dilaksanakan secara offline maupun daring karena dampak virus covid-19, guru bingung dalam memberikan motivasi belajar kepada siswa pada saat pembelajaran dilaksanakan, sehingga siswa tidak semangat dalam belajar. Selain itu siswa lebih sering bermain dengan teman-temannya dan tidak fokus dalam belajar.

Motivasi ekstrinsik adalah motif-motif yang aktif dan berguna karena adanya perangsang dari luar. Motivasi ekstrinsik dapat juga dikatakan sebagai bentuk motivasi. Aktivitas belajar dimulai dan dilanjutkan berdasarkan dorongan dari luar yang tidak secara mutlak berhubungan dengan aktivitas belajar (Sardiman, 2012).

Guru memiliki beberapa peranan penting dalam pembelajaran, yakni sebagai demonstrator, pengelola kelas, mediator, fasilitator, dan evaluator. Peran guru dalam pembelajaran dengan memberikan kemudahan kepada siswa untuk belajar agar siswa dapat berkembang secara optimal. Dalam hal ini guru harus kreatif, profesional, dan menyenangkan. Agar dapat tercipta motivasi dalam belajar, guru memiliki cara dan upaya untuk mencapai tujuan pembelajaran. Dengan demikian adanya motivasi belajar siswa dalam proses pembelajaran diperlukan adanya upaya yang harus dilakukan guru dalam memotivasi belajar siswa. Dari hasil penelitian (Pratiwi, 2019) upaya-upaya guru dalam memotivasi siswanya sebagai berikut.

a. Membangkitkan minat siswa.

Sebelum melakukan pembelajaran, guru harus membuat sebuah perangkat pembelajaran yang bersumber dari silabus disebut juga rancangan proses pembelajaran (RPP). Guru menggunakan bahasa yang mudah dipahami pada saat menyampaikan materi, guru melakukan pendekatan individu kepada siswa yang belum memahami materi ketika proses 
belajar mengajar, guru mengarahkan dan membimbing siswa untuk bisa mengikuti pelajaran dengan baik

b. Menciptkan suasana yang menyenangkan dalam belajar.

Guru membantu siswa mngembangkan kemampuan berpikir tahap tinggi, berfikir kritis, dan berpikir kreatif. Guru menyampaikan materi dengan sesekali bercanda agar siswa tidak bosan. Guru memperbanyak komunikasi kepada siswa, guru mengajak siswa berbaur dengan siswa lain dan melakukan permainan sambil belajar agar siswa tidak menjadi bosan untuk mengikuti pelajaran dan tidak merasa takut ketika guru menyampaikan materi pelajaran.

c. Komentar dan pujian yang tepat.

Pujian yang diberikan guru terhadap siswa berupa pujian yang positif yang dapat membangkitkan minat siswa untuk belajar dengan giat. Siswa diberikan pujian yang positif, dengan pujian siswa akan lebih giat belajar dan bisa mempertahankan nilainya.

d. Menciptakan persaingan dan kerjasama

Guru melibatkan semua siswa untuk melakukan persaingan baik antar individu maupun antar kelompok agar siswa dapat aktif dalam belajar. Guru menyampaikan materi secara lantang dan tegas, guru mgarahkan siswa dalam tugas kelompok, guru juga menggunakan alat peraga agar siswa lebih tertarik dan paham terhadap materi yang akan disampaikan. Selain itu, guru juga membimbing siswa untuk berinteraksi dengan teman sebaya dalam kegiatan kelompok. Guru mengajak siswa lain untuk saling membantu dalam mengerjakan tugas kelompok.

e. Memberikan penilaian

Guru memberikan kesempatan kepada siswa untuk mengikuti ujian ulang jika nilainya belum mencapai KKM, selain itu guru juga mengadakan jam belajar tambahan untuk menunjang nilai yang belum terpenuhi, guru lebih berperan aktif untuk memotivasi siswa dengan banyak melakukan pendekatan secara individu dan memberikan bimbingan penuh kepada siswa.

Terdapat hambatan yang terjadi dalam penguasaan materi pembelajaran dengan memotivasi belajar siswa. Diantaranya guru kurang dalam memotivasi belajar siswa semenjak pembelajaran dilakukan secara daring. Selain itu siswa memiliki karakter yang berbeda-beda dengan selera belajar masing-masing. Peran dan fungsi guru dalam meningkatkan mutu pendidikan menurut Usman (dalam Anugraheni, 2017) bahwa guru sebagai demonstrator berfungsi untuk mendemonstrasikan suatu materi pembelajaran, sehingga lebih mudah dimengerti dan dipahami oleh siswa. Oleh karena itu, guru harus mampu menguasai bahan atau materi pelajaran yang akan diajarkan serta senantiasa mengembangkan kemampuannya agar mampu memperagakan apa yang diajarkannya secara didaktis. 
Guru sebagai sumber belajar memiliki peran yang penting dan berkaitan erat dengan penguasaan materi pelajaran. Hal tersebut dapat menilai baik atau tidaknya seorang guru dalam penguasaan materi. Dikatakan guru yang baik jika ia dapat menguasai materi pelajaran dengan baik, sehingga benar-benar berperan sebagai sumber belajar bagi anak didiknya (Sundari, 2017). Guru akan yakin dalam menjawab seluruh pertanyaan siswa yang berkaita dengan materi pembelajaran. Sebagai sumber belajar dalam proses pembelajaran hendaknya guru melakukan beberpa hal, misalnya guru harus memiliki bahan referensi yang lebih banyak dibandingkan dengan siswa. Hal ini untuk menjaga agar guru memiliki pemahaman yang lebih baik tentang materi yang akan dikaji bersama siswa, guru dapat menunjukkan sumber belajar yang dapat dipelajari oleh siswa yang biasanya memiliki kecepatan belajar di atas rata-rata siswa yang lain, guru perlu melakukan pemetaan tentang materi pelajaran, misalnya dengan menentukan mana materi inti yang wajib dipelajari siswa. Melalui pemerataan akan memudahkan guru dalam melaksanakan tugasnya sebagai sumber belajar.

Dalam peranannya sebagai pengelola kelas (learning manager), guru hendaknya mampu mengelola kelas sebagai lingkungan belajar serta merupakan aspek dari lingkungan sekolah yang perlu diorganisasi. Lingkungan diatur dan diawasi agar kegiatan belajar terarah dan mencapai tujuan pendidikan. Pengawasan terhadap lingkungan belajar juga menentukan sejauh mana lingkungan tersebut menjadi lingkungan belajar yang baik. Lingkungan yang baik ialah yang bersifat menantang dan merangsang siswa untuk belajar, memberikan rasa aman dan kepuasan dalam mencapai tujuan.

Guru sebagai pengelola kelas berfungsi untuk mengendalikan dan mengorganisasikan siswa di dalam kelas agar lebih terarah pada tujuan pembelajaran. Oleh karena itu, guru harus mampu mengelola kelas karena kelas merupakan lingkungan belajar serta merupakan suatu aspek dari lingkungan sekolah yang perlu diorganisasikan (Anugraheni, 2017).

Guru sebagai pengelola pembelajaran. Tujuan umum pengelolaan kelas adalah menyediakan dan menggunakan fasilitas bagi bermacam-macam kegiatan belajar mengajar. Sedangkan tujuan khususnya adalah mengembangkan kemampuan siswa dalam menggunakan alat-alat belajar, menyediakan kondisi-kondisi yang memungkinkan siswa bekerja dan belajar, serta membantu siswa untuk memperoleh hasil yang diharapkan (Sundari, 2017). Selain itu, guru juga berperan dalam membimbing pengalaman sehari-hari ke arah pengenalan tingkah laku dan kepribadiannya sendiri. Salah satu ciri manajemen kelas yang baik adalah tersedianya kesempatan bagi siswa untuk sedikit demi sedikit mengurangi ketergantungannya hingga mereka mampu membimbing kegiatannya sendiri. Guru hendaknya mampu menggunakan pengetahuan tentang teori belajar mengajar dari teori perkembangan hingga memungkinkan untuk menciptaksan situasi belajar yang baik, mengendalikan pelaksanaan pengajaran, dan pencapaian tujuan. 
Guru sebagai mediator \& fasilitator. Guru hendaknya memiliki pengetahuan dan pemahaman yang cukup tentang media pendidikan. Media pendidikan merupakan alat komunikasi untuk lebih pengefektivan proses belajar mengajar. Dengan demikian, media pendidikan merupakan dasar yang sangat diperlukan yang bersifat melengkapi dan merupakan bagian integral demi keberhasilan proses pendidikan dan pengajaran di sekolah.

Sebagai fasilitator, guru hendaknya mampu mengusahakan sumber belajar yang berguna serta dapat menunjang pencapaian tujuan dan proses belajar mengajar, baik yang berupa narasumber, buku teks, majalah, ataupun surat kabar. Guru harus kreatif untuk menemukan sumber belajar yang bervariasi. Dengan sumber belajar yang baik maka akan menciptakan pembelajaran yang baik dan menyenangkan.

Sebagai fasilitator guru berperan dalam memberikan pelayanan untuk memudahkan siswa dalam kegiatan proses pembelajaran. Tujuan mengajar adalah mempermudah siswa belajar. Inilah hakikat peran fasilitator dalam proses pembelajaran. Agar dapat melaksankan peran sebagai fasilitator dalam proses pembelajaran, ada beberapa hal yang harus dipahami khususnya hal-hal yang berhubungan dengan pemanfaatan berbagai media dan sumber pembelajaran, diantarannya (1) guru perlu memahami berbagai jenis media dan sumber belajar beserta fungsi masing-masing media tersebut, (2) guru perlu memiliki keterampilan dalam merancang suatu media, (3) guru dituntut untuk mampu mengorganisasikan berbagai jenis media serta dapat memanfaatkan berbi sumber belajar, (4) sebagai fasilitator guru dituntut agar memiliki kemampuan dalam berkomunikasi dan berinteraksi dengan siswa (Sundari, 2017).

Guru sebagai mediator dan fasilitator berfungsi untuk memperagakan suatu media atau alat pembelajaran yang mendukung materi sehingga siswa lebih merasa jelas. Oleh karena itu, guru hendaknya memiliki pengetahuan dan pemahaman yang cukup tentang media pendidikan sebagai alat komunikasi guna mengefektifkan pembelajaran (Anugraheni, 2017).

Guru sebagai evaluator setiap jenis pendidikan atau bentuk pendidikan tentunya selama periode pendidikan seorang selalu diadakan evaluasi, artinya pada waktu-waktu tertentu selama satu periode pendidikan, selalu diadakan penilaian terhadap hasil yang telah dicapai, baik oleh pihak terdidik maupun oleh pendidik. Demikian pula dalam satu kali proses belajar mengajar, guru hendaknya menjadi seorang evaluator yang baik. Kegiatan ini dimaksudkan untuk mengetahui apakah tujuan yang telah dirumuskan itu tercapai atau belum, dan apakah materi yang diajarkan sudah cukup. Semua pertanyaan tersebut akan dijawab melalui kegiatan evaluasi dan penilaian.

Guru sebagai evaluator berfungsi untuk mengevaluasi hasil belajar siswa. Oleh karena itu guru harus melaksanakan evaluasi pada waktu-waktu tertentu selama satu periode pendidikan untuk 356 
mengadakan penilaian terhadap hasil yang telah dicapai, baik oleh pihak terdidik maupun oleh pendidik (Anugraheni, 2017).

Melalui penilaian, guru dapat mengetahui keberhasilan pencapaian tujuan, penguasaan peserta didik terhadap pelajaran, serta ketetapan atau keefektifan metode mengajar. Tujuan lain dari penilaian ini di antaranya ialah untuk mengetahui kedudukan peserta didik di dalam kelas atau kelompoknya. Melalui penilaian, guru dapat mengklasifikasikan apakah seorang peserta didik termasuk kelompok peserta didik yang pandai, sedang, kurang, atau cukup baik dikelasnya jika dibandingkan dengan teman-temannya.

Dari hambatan-hambatan tersebut dapat ditegaskan bahwa motivasi akan selalu berkaitan dengan kebutuhan. Kebutuhan tersebut timbul karena adanya keadaan tidak seimbang, tidak serasi atau rasa ketegangan yang menuntut suatu kepuasan. Keadaan yang tidak seimbang memerlukan motivasi yang tepat. Jika kebutuhan terpenuhi dan terpuaskan, maka akan timbul tuntutan kebutuhan baru. Hal ini menunjukkan bahwa motivasi belajar harus tetap diterapkan dalam pembelajaran oleh guru. Motivasi dapat menentukan ketekunan belajar. Seorang anak yang telah termotivasi untuk belajar sesuatu, akan berusaha mempelajarinya dengan baik dan tekun, dengan harapan memperoleh hasil yang baik.

\section{KESIMPULAN}

Berdasarkan hasil penelitian yang sudah dilakukan, dapat disimpulkan bahwa peran guru dalam memotivasi belajar siswa kelas V SDN 004 Sei Beberas Hilir, dalam kategori cukup baik meskipun terdapat hambatan yang dialami oleh guru untuk mendorong siswa lebih semangat dalam proses belajar. Karena dengan adanya dorongan yang diberikan oleh guru, maka siswa akan termotivasi dan bersemangat untuk belajar. Sehingga jiwa siswa akan tersentuh karena kasih sayang yang diberikan oleh guru kepada siswa. Berikut merupakan peran dan hambatan yang dialami guru.

1. Peran guru sangat penting terhadap keberhasilan belajar siswa dan siswi, maka dibutuhkan guru sebagai demonstrator yang mampu mempengaruhi siswa. Guru dituntut untuk menguasai materi dan harus lebih kreatif dalam pembelajaran. Guru sebagai mediator dan fasilitator dalam menyiapkan media pembelajaran dengan kreatif, selalu memberikan nasihat, dorongan dan motivasi agar siswa lebih semangat dalam belajar, guru sebagai evaluator dalam menilai siswa dengan kemampuannya masing-masing dan bersifat jujur dalam menilai.

2. Hambatan yang dialami oleh guru dalam memotivasi belajar siswa adalah pada saat pembelajaran secara daring karena dampak covit-19. Peran guru menjadi lebih kreatif dan inovatif, motivasi pembelajaran harus lebih diterapkan dalam pembelajaran. Hal itu karena jika 
tidak diterapkan akan berdampak kepada siswa, contohnya seperti siswa menjadi tidak semangat dalam pembelajaran, siswa tidak fokus dalam memperhatikan, serta lebih suka bermain dengan teman-temannya sehingga siswa pun menjadi lamban dalam belajar.

\section{DAFTAR PUSTAKA}

Supardi. (2013). Sekolah Efektif : Konsep Dasar dan Praktiknya. Jakarta: PT Rajagrafindo Persada. Sugiono, (2015). Metode Penelitian Kuantitatif. Kualitatif Dan R\&D. Bandung: Alfabeta.

Hero, Hermus \& Sni, Maria Ermalinda. (2018). Peran Orang Tua dalam Meningkatkan Motivasi Belajar Siswa Kelas V Di Sekolah Dasar Inpres Iligetang. Jurnal Riset Pendidikan Dasar, Vol. 01. No. 2 .

Kirom, Askhabul. (2017). Peran Guru Dan Peserta Didik Dalam Proses Pembelajaran Berbasis Multikultural. Jurnal Pendidikan Agama Islam, Vol. 3. No. 1.

Gunawan, Imam. (2014). Metode Penelitian Kualitatif: Teori Dan Praktik. Jakarta: PT Bumi Aksara. Anugraheni, Indri. (2017). Analisa Faktor-Faktor yang Mempengaruhi Proses Belajar Guru-Guru Sekolah Dasar. Jurnal Manajemen Pendidikan, Vol. 4. No. 2.

Sundari, faulina. (2017). Peran Guru sebagai Pembelajaran dalam Memotivasi Peserta Didik Usia $S D$. Jurnal prosiding diskusi panel pendidikan. Vol. no 1

Pratiwi, Dkk. (2019). Upaya Guru dalam Meningkatkan Motivasi Belajar Siswa Pada Mata Pelajaran PPKN Di SMP Negeri 13 Palembang. Jurnal Bhinneka Tunggal Ika, Vol. 6. No. 1. 